\title{
Choking risk among psychiatric inpatients
}

\author{
This article was published in the following Dove Press journal: \\ Neuropsychiatric Disease and Treatment \\ 17 June 2011 \\ Number of times this article has been viewed
}

\section{Takahiko Nagamine \\ 'Division of Psychiatric Internal Medicine, Seiwakai-Kitsunan Hospital, Suzenji, Japan}

Choking is a life-threatening and not infrequent occurrence in psychiatric hospitals. There is, however, little information available about the risk factors or methods to prevent choking. We conducted a retrospective analysis of the 8 patients who had a cardiopulmonary arrest due to choking and received resuscitation at our hospital during the 6-year period from April 2005 to March 2011. The study involved 6 males and 2 females, all of whom were patients with schizophrenia taking antipsychotics orally. They were aged from 56 to 79 (mean \pm SD: $69.0 \pm 7.5$ years), with the duration of illness from 28 to 54 years ( $39.9 \pm 7.9$ years). In 6 of the 8 cases, choking was diagnosed immediately on the basis of the situation at the time of cardiopulmonary arrest. In the remaining 2 cases, cardiopulmonary arrest was initially unexplained, and choking was only diagnosed subsequently. Choking was caused by bread in all cases. Tracheal intubation was carried out in all cases and resulted in successful resuscitation, causing no subsequent change in functions compared with the prechoking condition. All 8 patients had been receiving multiple antipsychotics before the event (mean number of drugs used $2.5 \pm 0.7$ ), with a total dose level ranging from 600 to $1800 \mathrm{mg}$ /day chlorpromazine equivalents (mean $1113 \pm 341 \mathrm{mg} /$ day). Seven of the 8 patients had mild to moderate involuntary movements, and 5 patients were diagnosed with antipsychotic-induced tardive dyskinesia. During the 5-year period before the choking event, 7 of the 8 patients had at least 1 treatment interruption, and some patients had up to 4 interruptions. On average, patients had 2.3 interruptions (mean $2.3 \pm 1.2$ times) during the preceding 5 -year period. Anti-Parkinsonian drugs were used in 6 of the 8 patients with mean dose of $2.6 \pm 1.7 \mathrm{mg} /$ day (biperiden equivalents). In 6 patients, hypnotic benzodiazepines had been prescribed at a mean dose of $10.6 \pm 9.2 \mathrm{mg} /$ day (diazepam equivalents). Pharyngeal reflex was checked after recovery by depressing the lingual root with a tongue depressor and was found to be was absent in all cases. Six of the 8 patients had frequent abnormal eating behaviors (such as fast eating, hidden eating) before the event. Only 2 of the 8 patients had a history of aspiration pneumonia.

The cases of choking in our study were characterized by a high proportion of male patients, long duration of illness, use of multiple antipsychotics, a history of interrupted antipsychotic use, locomotor disorders (extrapyramidal symptoms and tardive dyskinesia), loss of pharyngeal reflex and abnormal eating behaviors. These characteristic are similar to those reported for a group of Chinese war veterans. ${ }^{1}$

A history of aspiration pneumonia did not predict choking. Dysphagia induced by antipsychotics has been reported to increase the risk of both aspiration pneumonia and 
choking. ${ }^{2}$ Aspiration pneumonia arises from microaspiration causing the entry of small amounts of food and oral indigenous microbial flora into the trachea. It is often attributable to silent aspiration, and a major mechanism for its onset is reduction in throat reflex mediated by antipsychotic-induced decrease of substance $\mathrm{P}^{3}$ It is not always accompanied by extrapyramidal symptoms. Respiratory arrest in cases of choking is not, however, caused by entry of food into the trachea but by obstruction of the pharynx with food mass.

Locomotor disorders such as tardive dyskinesia are major risk factors for choking, and the risk is higher if accompanied by abnormal eating behaviors. ${ }^{4}$ Locomotor disorders due to antipsychotics are more likely to occur with the use of multiple antipsychotics at high doses, exceeding the level required for optimal dopamine D2 receptor blockade. In animal studies using antipsychotics, about 80\% D2 receptor blockade for 4 weeks resulted in upregulation of D2 receptors, increasing the risk for tardive dyskinesia. ${ }^{5}$ Longterm use of antipsychotics can also increase the risk for tardive dyskinesia mediated by D2 receptor upregulation. Interruption of antipsychotic use might thus be expected to reduce extrapyramidal symptoms. In practice, this appears not to be the case, since in our study, 7 of the 8 patients had experienced interruption of antipsychotic use before the event. Conversely, there are reports that interruption of antipsychotic treatment may increase the risk of extrapyramidal symptoms. ${ }^{6}$ In an animal study, intermittent treatment with antipsychotics was found to induce persistent vacuous chewing, suggestive of tardive dyskinesia. ${ }^{7}$ Extrapyramidal symptoms in animals also occurred more frequently when the degree of D2 blockade was rapidly increased by changes in blood antipsychotic drug levels ${ }^{8,9}$ To prevent choking, it is thus seems important to minimize locomotor disorders by optimizing the antipsychotic dose and avoiding sudden changes in D2 receptor blockade.

If a patient loses consciousness during a meal, it is easy to suspect a choking accident. However, if the event occurs during hidden eating an immediate diagnosis of choking is unlikely. Although food in the oral cavity would suggest choking, we had a case where respiratory arrest took place due to obstruction of the pharynx with food mass, with no food found in the oral cavity. Choking needs to be systematically considered as a possible cause of cardiopulmonary arrest in psychiatric inpatients.

Although choking is a severe complication in long-stay psychiatric inpatients, no major study has been conducted on this kind of event. A multicenter investigation into choking in psychiatric hospitals and guidelines for its prevention is clearly warranted.

\section{Disclosure}

The author declares no conflicts of interest.

\section{References}

1. Hwang SJ, Tsai SJ, Chen IJ, Hsu FC, Li C, Kao KP. Choking incidents among psychiatric inpatients: a retrospective study in Chutung Veterans General Hospital. J Chin Med Assoc. 2010;73:419-424.

2. Ruschena D, Mullen PE, Palmer S, et al. Choking deaths: the role of antipsychotic medication. Br J Psychiatry. 2003;183:446-450.

3. Nagamine T. Serum substance P levels in patients with chronic schizophrenia treated with typical or atypical antipsychotics. Neuropsychiatr Dis Treat. 2008;4:289-294.

4. Kumar MV, Venkatesh VT, Jagannatha SR. Fast eating syndrome: a case report. Med Sci Law. 2008;48:78-81.

5. Ginovart N, Wilson AA, Hussey D, Houle S, Kapur S. D2-receptor upregulation is dependent upon temporal course of D2-occupancy: A longitudinal $\left[{ }^{11} \mathrm{C}\right]$-Raclopride PET study in cats. Neuro psychopharmacology. 2009;34:662-671.

6. Van Harten PN, Hoek HW, Matroos GE, Koeter M, Kahn RS. Intermittent Neuroleptic Treatment and Risk for Tardive Diskinesia: Curacao Extrapyramidal Syndromes Study III. Am J Psychiatry. 1998;155:565-567.

7. Glenth $\not j$ B. Persistent vacuous chewing in rats following neuroleptic treatment: relationship to dopaminergic and cholinergic function. Psychopharmacology. 1993;113:157-166.

8. Ereshefsky L, Mascarenas CA. Comparison of the effects of different routes of antipsychotic administration on pharmacokinetics and pharmacodynamics. J Clin Psychiatry. 2003;64(Suppl 16):18-23.

9. Marchese G, Casu G, Casti P, Spada GP, Pani L. Evaluation of amphetamine-induced hyperlocomotion and catalepsy following long-acting risperidone administration in rats. Eur J Pharmacol. 2009;620:36-41.
Neuropsychiatric Disease and Treatment

\section{Publish your work in this journal}

Neuropsychiatric Disease and Treatment is an international, peerreviewed journal of clinical therapeutics and pharmacology focusing on concise rapid reporting of clinical or pre-clinical studies on a range of neuropsychiatric and neurological disorders. This journal is indexed on PubMed Central, the 'PsycINFO' database and CAS, and is the official

\section{Dovepress}

journal of The International Neuropsychiatric Association (INA). The manuscript management system is completely online and includes a very quick and fair peer-review system, which is all easy to use. Visit $\mathrm{http}: / /$ www.dovepress.com/testimonials.php to read real quotes from published authors. 